\title{
COMMENTS
}

\section{THE CORPORATE PLAINTIFF AND VENUE UNDER SECTION 1391(C) OF THE JUDICIAL CODE}

In actions brought in federal courts plaintiffs generally must lay venue in conformity with section 1391 of the Federal Judicial Code.1 Section 1391(a) provides that in diversity cases venue is properly laid in any judicial district in which all of the plaintiffs or all of the defendants reside. ${ }^{2}$ Section 1391(c), which modifies this diversity provision as applied to corporations, provides: "A corporation may be sued in any judicial district in which it is incorporated or licensed to do business or is doing business, and such judicial district shall be regarded as the residence of such corporation for venue purposes." 3 The district courts have had no difficulty in applying this section to corporate defendants, 4 but they have divided on the applicability of the section to corporate plaintiffs.

I

Seven district courts 5 have upheld the right of plaintiff corporations to bring actions in districts in which they were licensed to do business or were doing business, on the ground that section 1391(c) brought those districts within the residence requirement of section 1391(a). Three district courts 6 have

128 U.S.C. $\S 1391$ (1958). This section is the general venue provision. Venue provisions controlling in special cases are found in sections 1392-1403 of title 28 as well as in various other statutes such as the Federal Employer's Liability Act, 62 Stat. 989 (1948), 45 U.S.C. $\S 56(1958)$.

2 "A civil action wherein jurisdiction is founded only on diversity of citizenship may, except as otherwise provided by law, be brought in the judicial district where all plaintiffs or all defendants reside." 28 U.S.C. § 1391(a) (1958).

328 U.S.C. $\$ 1391$ (c) (1958). This section first appeared in the 1948 Judicial Code Revision.

4 See, e.g., Carlisle v. Kelly Pile \& Foundation Corp., 175 F.2d 414 (3d Cir. 1949), in which the court discusses the background of the section as applied to corporate defendants.

5 See Freiday v. Cowdin, 83 F. Supp. 516 (S.D.N.Y. 1949); Hadden v. Barrow, Wade, Guthrie \& Co., 105 F. Supp. 530 (N.D. Ohio 1952); Ralston Purina Co. v. United States, 1952 Am. Mar. Cas. 1496 (E.D. La. 1952); Southern Paperboard Corp. v. United States, 127 F. Supp. 649 (S.D.N.Y. 1955); Eastern Motor Express, Inc. v. Espenshade, 138 F. Supp. 426 (E.D. Pa. 1956); Standard Ins. Co. v. Isbell, 143 F. Supp. 910 (E.D. Tex. 1956); Traveler's Ins. Co. v. Williams, 164 F. Supp. 566 (W.D.N.C. 1958). Contemporaneous to the Federal Judicial Code revision, two writers predicted the possibility of such an interpretation. See Note, The Proposed Revision of the Federal Judicial Code, 60 HaRV. L. Rev. 424, 435 (1947); Wechsler, Federal Jurisdiction and the Revision of the Judicial Code, 13 LAW \& CONTEMP. Prob. 216, 240 n.126 (1948).

6 See Chicago \& N.W. Ry. v. Davenport, 94 F. Supp. 83 (S.D. Iowa 1950); Albright \& Friel, Inc. v. United States, 142 F. Supp. 607 (E.D.Pa. 1956); Nebraska-Iowa Bridge Corp. v. United States, 158 F. Supp. 796 (D. Neb. 1958). Two other district courts have indicated in 
rejected that view and have refused to entertain actions brought by corporations in districts in which they were not residents within the traditional test 7 of corporate residence. In the view of the latter courts, section 1391(c) merely continued the policy, expressed in other areas, ${ }^{8}$ of making non-resident corporations subject to suit in the districts in which they are doing business.

In Freiday v. Cowdin 9 the first district court to be presented with this controversial problem of interpretation upheld the right of a plaintiff corporation to base venue on the provisions of section 1391(c). The plaintiff, a stockholder in a Delaware corporation, brought a derivative action against a California resident in the Southern District of New York. Since section 1401 allows a stockholder in a derivative suit to lay venue in any district in which the corportation could have sued the same defendant, 10 the case posed the question of whether the corporation itself could have sued the defendant in that district. The defendant moved to dismiss on the ground that venue was improper under section 1391(a). ${ }^{11} \mathrm{He}$ argued that, since he was a resident of California, and the corporation was, under the traditional test of residence, a resident of Delaware, the Southern District of New York was neither the residence of all the plaintiffs nor of all the defendants. The plaintiff argued that section 1391(c) made the corporation a resident of any judicial district in which it was licensed to do business. Since the corporation was licensed to do business in the Southern District of New York the plaintiff concluded that it was a resident of that district, and that venue was proper under section 1391(a). The court accepted the argument that section 1391(c) defined corporate residence and denied the motion to dismiss, stating:

dicta that if called upon to decide the question they would prefer this interpretation of section 1391(c). United Merchants \& Mfrs. Inc. v. United States, 123 F. Supp. 435 (M.D. Ga. 1954); United Transit Co. v. United States, 158 F. Supp. 856 (M.D. Tenn. 1957).

7 In a long line of cases from Shaw v. Quincy Mining Co., 145 U.S. 444 (1892) to Suttle v. Reich Bros. Constr. Co., 333 U.S. 163 (1948), the Supreme Court had held that the residence of a corporation was the state of incorporation. Where that state was composed of more than one judicial district, the residence was in the district in which the head office was maintained. Galveston, H. \& S.A. Ry. v. Gonzales, 151 U.S. 496 (1894).

8 This policy is evidenced by the increased amenability to suit brought about by the relaxation of the standards of "presence" required for jurisdiction over corporations. See Kurland, The Supreme Court, The Due Process Clause, and the In Personam Jurisdiction of State Courts, 25 U. CHI. L. Rev. 569 (1958).

983 F. Supp. 516 (S.D.N.Y. 1949).

10 "Any civil action by a stockholder on behalf of his corporation may be prosecuted in any judicial district where the corporation might have sued the same defendant." 28 U.S.C. $\S 1401$ (1958).

11 The motion actually made was one "to vacate and set aside the service of the summons and complaint." Since such a motion raises the question of jurisdiction over the person of the defendant rather than the issue of proper venue, the defendant's argument was not properly before the court. The court, however, treated the motion as the one which should have been made, i.e., a motion to dismiss for improper venue. For purposes of clarity the motion is treated in the text as a motion to dismiss for improper venue. 
To give full effect to the words "and such judicial district shall be regarded as the residence of such corporation for venue purposes," one must conclude that they refer to both plaintiff and defendant corporations. To conclude otherwise one would have to attribute to Congress the anomalous intent to define the residence of corporate defendants but not that of corporate plaintiffs. Under such interpretation there would be nothing in the Code defining the residence of corporate plaintiffs under Section 1391(a). Furthermore, corporations would be amenable to suit in jurisdictions in which they were licensed to do business or were doing business, but they could not sue as plaintiffs in those very same districts unless all defendants were residents of that district.12

The Freiday interpretation was rejected in Chicago \& N.W. Ry. v. Davenport 13 by the second district court to consider the applicability of section 1391(c) to corporate plaintiffs. A Wisconsin corporation sued Texas residents in the Southern District of Iowa, where the corporation was doing business. The plaintiff urged the Freiday precedent, arguing that section 1391(c) made it a resident of the Iowa district to satisfy the residence requirement of section 1391(a). The court refused to follow Freiday on the ground that the legislative and judicial history of the federal venue provisions generally were understood to require a more restrictive interpretation of venue provisions than was consonant with the Freiday holding. 14 The court held the section applicable only to defendant corporations.

The Freiday interpretation was next considered in Hadden v. Barrow, Wade, Guthrie \& Co.15 The trustee in bankruptcy of a Delaware corporation brought suit in the Northern District of Ohio, where the corporation was licensed to do business, against a partnership whose members were not all residents of that district. The defendants moved to dismiss for improper venue on the ground that section 1391(a) required that venue be laid in the district which was the residence of "all defendants." In denying the motion to dismiss, the court accepted the Freiday interpretation of section 1391(c) and added an argument of its own:

[H] ad the framers of the statute intended to confine venue to defendant corporations, the language "and such judicial district shall be regarded as the residence of such corporation for venue purposes" would be meaningless and redundant in the face of the clear, expressive and unambiguous wording which precedes it. ${ }^{16}$

The remainder of the cases interpreting this section ${ }^{17}$ have merely followed Freiday and Hadden or Chicago \& N.W. Ry. without adding to the rationales for these conflicting interpretations of section 1391(c).

1283 F. Supp. at 517-18.

1394 F. Supp. 83 (S.D. Iowa 1950).

14 Id. at 84-85.

15105 F. Supp. 530 (N.D. Ohio 1952).

$16 \mathrm{Id}$. at 531.

17 Cases cited notes 5 \& 6 supra. 
Venue, like jurisdiction, is an administrative requirement of the judicial system. The purpose of venue requirements is the determination of the place of trial. There is no necessity that that place be fixed by reference to residence; some other criterion could be used.18 Historically, however, federal venue statutes have used residence as the criterion in diversity cases. 19 The Freiday court correctly read section 1391 (a) as continuing that policy..$^{20}$ The court then assumed that section 1391(c) was a test of corporate residence to be used in the application of section 1391(a).

It is not clear why the court made that assumption; a test of residence is, of course, prerequisite to the application of section 1391(a), but nothing indicates that the test will be found in the venue statutes. More specifically, nothing in section 1391 indicates that section 1391(c) is a test of corporate residence supplied by Congress as an aid in applying section 1391(a) to corporate parties. Section 1391(c) itself does not support that assumption; the language "shall be regarded as the residence" is incompatible with the premise that the section defines districts of which the corporation "shall be" a resident. If one makes this assumption, however, the Freiday reasoning is persuasive for it would have been anomalous for Congress to have defined residence for corporate defendants but not for corporate plaintiffs. 21

The Hadden court made the same unexplained assumption the basis for its redundancy argument. The court found that the "clear, expressive and unambiguous" wording of the first clause-“"A corporation may be sued in any judicial district in which it is incorporate or licensed to do business or is doing business"-defined the residence of corporate defendants. Such a finding could not have been made without first assuming that the clause was a definition, for nothing in the clause itself equates the enumerated districts with corporate residence. Committed to this assumption, the Hadden court characterized the "shall be regarded" wording of the second clause as "vague and ambiguous." The court then avoided redundancy by interpreting the "ambiguous" language as applying not only to corporate defendants, but also to corporate plaintiffs. The possibility that the language was "vague and ambigu-

18 For example, section 1400 provides that in patent infringement cases venue may be laid in any district where the defendant has committed an act of infringement and has a place of business. 28 U.S.C. $\$ 1400$ (1958).

19 The residence provision has been in force since the Judiciary Act of 1789. 1 Stat. 79 (1789).

20 The Reviser's Notes clearly indicate that this was the congressional intent. Reviser's Notes, following 28 U.S.C.A. § 1391 (1958).

21 See 83 F. Supp. at 518 . However, the assumption itself attributes an equally anomalous intent-Congress intended to define residence for corporations but not for any other juridical entity. It should be noted that it would not have been anomalous for Congress to have written a venue provision applicable only to corporate defendants for prior cases show that that was the problem which had to be resolved. See text at notes 28-33 infra. 
ous" because of the impropriety of the court's initial assumption was not explored.

There is an alternative assumption which makes the entire section meaning-, ful and clear, and it is suggested that such an interpretation is more logical than one which imputes poor draftsmanship to Congress. The alternative is that section 1391(c) is an independent venue provision applicable only to actions in which the defendant is a corporation. That is, section 1391(c) substitutes a new venue provision for the general provision of section 1391(a).

Treating section 1391(c) as an independent venue provision makes its first clause inconsistent with section 1391(a) because under that clause a corporation can be sued in a district other than that of its residence. 22 This inconsistency suggests the meaning of the second clause of section 1391(c)-"and such judicial district shall be regarded as the residence of such corporation for venue purposes." This language tacitly admits that the corporation is not a resident of all the districts in which it can be sued, but makes proof of the real corporate residence immaterial, thus removing the conflict between the sections. Since the interpretation of section 1391(c) as an independent venue provision makes all of the language of the section meaningful, clear, and necessary, it is submitted that this is the proper interpretation. Although none of the district courts considering the applicability of section 1391(c) to corporate plaintiffs has used the suggested analysis, ${ }^{23}$ legislative history, while inconclusive, appears to support it.

Congressional intent in the enactment of section 1391(c) can be ascertained only indirectly because of its limited legislative history. The section provoked no comment or debate; no direct reference to it can be found. However, generalized statements about the venue provisions ${ }^{24}$ and the entire revision ${ }^{25}$ demonstrate that no substantive law changes were intended except those noncontroversial changes which the Reviser's Notes indicate. ${ }^{26}$ According to the Reviser's Notes the only change which section 1391(c) made was a change in language, not of law.27

22 Section 1391(a) is not an exclusive provision, but rather one applicable "except where otherwise provided by law."

${ }^{23}$ The court in Chicago \& N.W. Ry. v. Davenport, 94 F. Supp. 83 (S.D. Iowa 1950), rejected Freiday because it could not believe that Congress had intended the Freiday result and not because it reached a different conclusion based on its own analysis of the section.

${ }^{24}$ See H. R. REP. No. 308, 80th Cong., 1st Sess. 6 (1947); Hearings before Subcommittee No. 1 of the Committee on the Judiciary on H.R. 1600 and H.R. 2055, 80th Cong., 1st Sess. 29 (1947).

${ }^{25}$ See Hearings before Subcommittee No. 1 of the Committee on the Judiciary on H.R. 1600 and H.R. 2055, supra note 22, at 6; 94 CONG. REC. 7928 (1948).

26 "[M]inor changes were made in the provisions regulating the venue of district courts in order to clarify ambiguities or to reconcile conflicts. These are reflected in the reviser's notes under sections 1391-1406." H. R. REP. No. 308, supra note 22, at 6.

${ }^{27}$ The Reviser's Note reads: "In subsection (c), references to defendants 'found' within a district or voluntarily appearing were omitted. The use of the word 'found' made section 111 
The need for a change in the language was clear. The venue provision of the Judiciary Act of 1789 was drafted in language applicable only to non-corporate litigants. ${ }^{28}$ With the increased use of the corporate form the courts had the problem of applying that language to corporate entities. The venue problem was magnified by restrictive interpretations under which corporations could engage in interstate activities while enjoying immunity from suit in all districts other than their residence. Much of the controversy centered around the question of where a corporation could be "found." A temporary answer was given in Ex parte Schollenberger. 29 The Supreme Court held that when a corporation, in compliance with state licensing laws, appointed an agent to receive service of process in the state, it was "found" in the state. However, the "found" wording was deleted in the Judiciary Act of 188730 and the corporate venue problem was once again presented. In Neirbo v. Bethelehem Shipbuilding Corp. 31 the Supreme Court held that a corporation waived its right to object to improper venue when, in compliance with state licensing law, it appointed an agent to receive service of process in the state. 32 The weakness of the Neirbo doctrine lay in its requirement of a specific positive action by the corporation for a finding of waiver of the venue privilege. 33 If the corporation chose not to comply with a state's license law, at the expense of the right of access to the state's courts, there was no waiver. The problem that the draftsmen had to resolve was thus not one of changing the definition of corporate residence, but rather one of codifying Neirbo and expanding it to include corporations "doing business" within the state, regardless of whether they had complied with the state's license law.

of 28 U.S.C., 1940 ed., ambiguous. The argument that an action could be brought in the district where one defendant resided and a nonresident defendant was 'found' was rejected in Camp v. Gress, 1919, 39 S. Ct. 478, 250 U.S. 308, 63 L. Ed. 997 . However, this ambiguity will be obviated in the future by the omission of such reference." Reviser's Notes, following 28 U.S.C. $\$ 1391$ (1958).

28 " [N] civil suit shall be brought ... against an inhabitant of the United States, by any original process in any other district than that whereof he is an inhabitant, or in which he shall be found at the time of serving the Writ ...."1 Stat. 79 (1789).

2996 U.S. 369 (1877).

30 "[N]o civil suit shall be brought before either of said courts against any person by any original process or proceeding in any other district than that whereof he is an inhabitant; but where the jurisdiction is founded only on the fact that the action is between citizens of different States, suit shall be brought only in the district of residence of either the plaintiff or the defendant ...." 24 Stat. 552 (1887), as amended, 25 Stat. 434 (1888).

31308 U.S. 165 (1939).

32 Much of the "unfairness" of allowing corporations to be sued in districts where they could not sue as plaintiffs comes not from section 1391(c) as the Freiday court assumed (see 83 F. Supp. at 518), but from Neirbo.

${ }^{33}$ For example, a corporation could not waive venue by impliedly consenting to suit in the state courts under a non-resident motorist statute. Olberding v. Illinois Cent. R.R., 346 U.S. 338 (1953). 
Indeed, the Chief Reviser of the Code has stated that "there was no purpose on the part of the Revision staff to effect any changes in existing law." 34 Articles written by members of the revision staff ${ }^{35}$ make no special mention of section 1391(c), although the venue provisions are discussed by each of them. Of course, the statements in those articles that no substantive law changes were to be inferred from the fact of revision does not preclude the possibility that a change was made. ${ }^{36}$ Yet when these statements are coupled with the expressed congressional intent not to make any changes, it would seem proper to conclude that that interpretation of section 1391(c) which makes the least change in prior law is the correct interpretation.

If section 1391(c) is a criterion of venue only in cases involving corporate defendants, as suggested, it makes little change in the prior law. Since corporations were residents of the district of incorporation, they were previously suable there. The "licensed to do business" phrase appears to be a codification of Neirbo v. Bethlehem Shipbuilding Corp. .37 and the "doing business" phrase seems designed to apply to corporations which, by non-compliance with state license law, avoided waiver under the Neirbo doctrine.

On the other hand, if section 1391(c) is treated as a general definition of corporate residence "for venue purposes," a rather broad change in existing law was made by the revision. Prior cases had unambiguously established that a corporation was a resident only of that district in the state of incorporation where it maintained its head office. ${ }^{38}$ The Freiday-Hadden interpretation of section 1391(c) would make a corporation a resident, for venue purposes, of many districts. That Congress intended a change in the definition of corporate residence is not only negated by what legislative history there is, but by the fact that no problem of the corporate parties' residence was discussed by Congress. When that legislative silence is coupled with the history of corporate venue provisions, the inference may be drawn ${ }^{39}$ that Congress intended no change in prior law. 40

34 Barron, The Judicial Code, 1948 Revision, 8 F.R.D. 439, 441 (1948). See also H.R. REP. No. 308, supra note 24, at 7; S. REP. No. 1559, 80th Cong., 2d Sess. 7 (1948).

35 Holtzoff, The New Federal Judicial Code, 8 F.R.D. 343 (1948); Galston, An Introduction to the New Federal Judicial Code, 8 F.R.D. 201 (1948); Maris, New Federal Judicial Code, 1948, 34 A.B.A.J. 863 (1948).

36 However, the Supreme Court has made reference to these statements, and accepted their import, in dealing with the relationship between section 1391(c) and section 1400 . Fourco Glass Co. v. Transmirra Prod. Co., 353 U.S. 222, 227 (1957).

37308 U.S. 165 (1939).

38 See note 7 supra.

39 A similar inference, based upon prior case history, lack of agitation for change, and congressional silence, was recently drawn by the Supreme Court in Romero v. Int'l Terminal Operating Co., 358 U.S. 354, 369 (1959).

40 This inference is further strengthened by the fact that section 1391(c) reads "shall be regarded" rather than "shall be." If Congress had meant to deal with the problem of corporate residence it would probably have couched the solution in the more positive form. 
Though the legislative history fails to support the Freiday-Hadden interpretation, it has been suggested that this view can be supported on policy grounds.41 It is argued that section 1391(a), which limits venue to the place of residence of the parties, is too restrictive because neither of the districts need be the district in which the events of the case occurred, 42 i.e., the forum conveniens. 43 Increasing the number of forums, it is said, increases the probable availability of the forum conveniens, and, since the Freiday-Hadden interpretation increases the number of forums available to corporate plaintiffs, it is desirable.

This argument's basic assumption, that a federal venue statute controlling diversity actions should make the forum conveniens available, is open to question. Presumably diversity jurisdiction is based upon the assumed prejudice against non-residents exhibited in state courts. 44 Diversity jurisdiction should be available where that prejudice exists. If the forum conveniens is not the residence of either party, the basis for diversity jurisdiction is missing 45 and there is no need for the federal courts in that district to hear the suit. It would appear that section 1391(a) is as broad as the rationale of diversity jurisdiction requires. The argument that section 1391(a) is too restrictive, because it does not make the forum conveniens available, is in reality an attack upon diversity jurisdiction policy as a whole. 46 As such, it would seem im-

${ }_{41}$ Note, Federal Venue and the Corporate Plaintiff: Judicial Code Section 1391(c), 28 IND. L.J. 256, 262-64 (1953). No policy arguments for expanding the choice of forums for plaintiff corporations were offered prior to the 1948 revision.

42 An example in point is Olberding v. Illinois Cent. R.R., 346 U.S. 338 (1952). One of the railroad's bridges in western Kentucky was so damaged by defendant's truck that a derailment subsequently occurred. The railroad brought suit in the district court for the Western District of Kentucky, clearly a forum conveniens. However, the railroad was an Illinois corporation and the trucking company an Indiana resident, so that the Western District of Kentucky was not the district of residence of either party. Although the corporation was doing business in the Kentucky district it did not urge the Freiday-Hadden interpretation as a basis for its laying venue there, but argued instead that there was a waiver under the state's non-resident motorist statute. The Supreme Court refused to extend a doctrine based upon real waiver to a situation in which waiver was fictional.

The same problem can arise where neither party is a corporation. See McCoy v. Siler, 205 F.2d 498 (3d Cir. 1953), cert. denied, 346 U.S. 872 (1953).

43 The forum conveniens may merely be a forum convenient for the parties, but as used here it means that forum where the court may view the premises, where it is convenient for the witnesses and where it is no hardship for the parties to appear. $C f$. Gulf Oil Corp. v. Gilbert, 330 U.S. 501 (1947).

${ }^{44}$ This is not the only rationale for diversity jurisdiction, nor is it necessarily historically accurate. See Friendly, The Historic Basis of Diversity Jurisdiction, 41 HARV. L. REV. 483 (1928). However, it is the rationale compatible with the congressional treatment of diversity jurisdiction requirements.

45 In such a case there will either be no prejudice because neither is a "preferred" party or the prejudice will be against both parties and will presumably cancel out.

46 The same argument was presented in McCoy v. Siler, 205 F.2d 498 (3d Cir. 1953). In reply to the policy arguments urged for judicial expansion of the venue provision, the court stated that "the only policy consideration which is apparent is that we should not be astute to widen federal diversity jurisdiction." Id. at 501. 
proper to base the interpretation of section 1391(c) on one's views regarding the controversial question of diversity jurisdiction.

Further, a broad interpretation of section 1391(c) is at best a half-measure if one really wishes to make the forum conveniens available. All that the Freiday-Hadden interpretation accomplishes is an increase in the probable availability of the forum conveniens. It cannot assure the availability of the appropriate forum in every case. If an accident were to occur in a district where the plaintiff was not a resident within the Freiday-Hadden interpretation, and the defendant was not a resident, venue would be improper in the forum conveniens despite the broad interpretation. 47

The forum conveniens argument also assumes that, given a choice of forums, one of which is the forum conveniens, the plaintiff will choose that forum. It does not necessarily follow, however, that the plaintiff will make such a choice. 48 Motivating the plaintiff's choice of forum may be a desire to harass the defendant, or the availability of a longer statute of limitations, 49 or the presence of more friendly choice-of-law rules, 50 or a helpful public policy, 51 or perhaps the desire for a jury in an area with a reputation for large money judgments. It would seem as likely that plaintiffs will forum-shop as that they will choose the forum conveniens.

To counter such forum shopping under the Freiday-Hadden interpretation, it has been suggested 52 that the courts employ section 1404(a),53 the federal change of venue provision. The efficacy of this solution seems doubtful. Section 1404(a) transfers are granted at the discretion of the judge; they are not available as of right. Rather, they are limited by the requirements that: (1) transfer be shown to be fordy he convenience of the parties and witnesses and in

47 For example, if a corporation's vehicle were struck by a non-resident motorist in a state where the corporation was not licensed to do business or was not doing business, the Freiday-Hadden interpretation would not make the forum conveniens available. See Martin v. Fishbach Trucking Co., 183 F.2d 53 (1st Cir. 1950).

48 In Ralston Purina Co. v. United States, 1952 Am. Mar. Cas. 1496 (E.D. La. 1952), a Missouri corporation used the Freiday-Hadden interpretation to lay venue in Louisiana for a suit to recover for cargo damage occurring in Puerto Rico. Whatever may have been the plaintiff's motive for laying venue in Louisiana, it is not apparent that that was the forum conveniens.

49 A federal court must apply the state statute of limitations. Moore v. Illinois Cent. R.R., 312 U.S. 630 (1940).

50 Under the Erie doctrine a federal court must apply the state's confict of laws rules. Klaxon Co. v. Stentor Elec. Mfg. Co., 313 U.S. 487 (1941).

51 A federal court must apply the public policy of the state in which it is sitting. Griffin v. McCoach, 313 U.S. 498 (1941).

52 See Note, supra note 41, at 262.

53 "For the convenience of parties and witnesses, in the interest of justice, a district court may transfer any civil action to any other district or division where it might have been brought." 28 U.S.C. § 1404(a) (1958). 
the interests of justice, 54 and (2) that the transferee forum be one in which the action could have originally been brought. 55

A serious objection to the section 1404(a) solution is the problem of the choice of law to be applied by the transferee forum. ${ }^{56}$ For example, if a forumshopping corporation, motivated by considerations of the statute of limitations, were to choose a forum where the statute had not run and then was transferred to a forum where it had, which statute of limitations should the transferee forum apply? 57 It has been suggested that the transferee forum should apply the statute of the transferor forum, or alternatively, that the defendant should have to waive the defense in order to get the transfer. ${ }^{58}$ In either case the corporation would get the benefits of its forum shopping and at the same time share in the benefits of trial in the forum conveniens. Such a result would be more likely to encourage forum shopping, rather than to put an end to it.

It is submitted that section 1391 (c) is not a definition of corporate residence as the Freiday-Hadden interpretation assumes. Both the legislative history and an analysis of section 1391 indicate that section 1391(c) is a separate venue provision to be used in actions in which the defendant is a corporation. So treated, section 1391(c) is not applicable to corporate plaintiffs.

54 This language may well require that the transferee forum be the forum conveniens. Cf. Gulf Oil Corp. v. Gilbert, 330 U.S. 501 (1947). If so, there could be no transfer in those cases where the Freiday-Hadden interpretation had not made that forum available.

55 This means where it could have been brought with proper jurisdiction and proper venue. The defendant may not get a transfer if either jurisdiction or venue would not have been proper without his waiver. Hoffman v. Blaski, 363 U.S. 335 (1960). But see Continental Grain Co. v. Barge FBL-585, 364 U.S. 19 (1960).

56 For a discussion of the problem, see Currie, Change of Venue and the Confict of Laws, 22 U. CHI. L. REv. 405 (1955); Currie, Change of Venue and the Conflict of Laws: A Retraction, 27 U. CHI. L. REv. 341 (1960).

57 This was the question posed in Headrick v. Atchison, T. \& S.F. Ry., 182 F.2d 305 (10th Cir. 1950).

58 Id. at 308-09.

\section{PERCENTAGE DEPLETION AND THE INTEGRATED MINER-MANUFACTURER}

Two different forums have recently re-examined and redefined the base for the percentage depletion deduction. ${ }^{1}$ The United States Supreme Court restricted the application of the controversial phrase, "ordinary treatment proc-

1 The percentage depletion deduction has been one of the most publicized and controversial deductions in our present tax system. See generally Goulette, Depletion for Tax Purposes: A Condensed Picture of How it Works in Mining, 4 J. TAXATION 258 (1956); Macleod, Percentage Depletion Controversy, 99 J. Accountancy 40 (1955). See also Note, 20 U. PITT. L. Rev. 155 (1958); Note, 28 Geo. Wash. L. Rev. 666 (1960); Note, 108 U. PA. L. Rev. 758 (1960); Tax Notes, 46 A.B.A.J. 1136 (1960). 